\title{
MODEL PEMBELAJARAN INKLUSI PADA MATA PELAJARAN IPS TERPADU DI SMP NEGERI 4 PAYAKUMBUH
}

\author{
Syirwana Mayasari HB \\ Pendidkan Sejarah STKIP Abdi Pendidikan Payakumbuh \\ Nahdatul Hazmi \\ Pendidkan Sejarah STKIP Abdi Pendidikan Payakumbuh \\ nahdatulhazmi1979@gmail.com
}

\begin{abstract}
Abstrak
Penulisan ini dilatar belakangi oleh adanya anggapan bahwa tempat belajar anak-anak difabel adalah Sekolah Luar Biasa (SLB), padahal banyak sekolah yang dapat dimasuki oleh siswa difabel sebagai tempat belajar, atau yang dikenal dengan pendidikan inklusi. Pendidikan inklusi adalah pendidikan yang menampung dan mendidik siswa-siswinya tanpa melihat bentuk dan kemampuan fisik maupun psikis. Semua dapat mengikuti pendidikan dilembaga tersebut, tanpa diskriminasi, dan mendapat perlakuan sama. SMPN 4 Payakumbuh melaksanakan pendidikan inklusi mulai tahun 2003. Sekolah ini menerima dan mendidik siswa difabel sebagaimana layaknya siswa-siswi yang lain. Model pembelajaran inklusi yang digunakan di SMPN 4 Payakumbuh antara lain: a) bentuk kelas reguler (inklusi penuh) yaitu menyatukan peserta didik normal dengan peserta didik berkebutuhan khusus (inklusi penuh) dibawah pengawasan guru kelas atau guru mata pelajaran dan guru pendamping khusus dengan memakai Kurikulum Sekolah yaitu Kurikulum 2013, dimana RPP dan Silabus tidak ada pemodifikasian bagi siswa berkebutuhan khusus (ABK), b) kelas regular dengan pull out yaitu anak berkebutuhan khusus belajar bersama anak normal lainnya dikelas reguler, namun dalam waktu-waktu tertentu ditarik dari kelas reguler ke ruang lain untuk belajar dengan guru pendamping khusus(GPK). Hambatan yang ditemui antara lain: guru pembimbing khusus (GPK) yang tidak memadai dengan jumlah peserta didik ABK di SMP Negeri 4 Payakumbuh dan kurangnya pemahaman guru umum mengenai pendidikan inklusi. Dan untuk nilai hasil belajar siswa berkebutuhan khusus cukup baik, namun masih terdapat sebagian anak ABK yang dibawah rata-rata KKM. Untuk itu baik guru kelas maupun guru mata pelajaran memberikan remedial ataupun tugas sebagai perbaikan nilai siswa ABK tersebut.
\end{abstract}

Kata Kunci : Model pembelajaran Inklusi, Siswa Difabel, IPS Terpadu

\begin{abstract}
Absract
This writing is motivated by the assumption that learning places for disabled children are Special Schools (SLB), even though many schools can be entered by disabled students as learning places, or what is known as inclusive education. Inclusive education is education that accommodates and educates students without seeing physical or psychological form and abilities. All can take education in the institution, without discrimination, and get the same treatment. Payakumbuh Middle School 4 carried out inclusive education starting in 2003. The school received and educated students with disabilities as other students. Inclusion learning models used in Payakumbuh Junior High School 4 include: a) the form of regular classes (full inclusion) which is to unite normal students with students with special needs (full inclusion) under the supervision of class teachers or subject teachers and special accompanying teachers using the curriculum Schools are Curriculum 2013, where RPP and Syllabus there is no modification for students with special needs (ABK), b) regular classes with pull out, namely children with special needs to learn with other normal children in the regular class, but at certain times withdrawn from regular classes to another space for learning with a special assistant teacher (GPK). The obstacles encountered include: inadequate tutor teachers (GPK) with the number of ABK students in SMP Negeri 4 Payakumbuh and lack of general understanding of inclusive education. And for the value of learning outcomes of students with special needs is quite good, but there are still some children with $A B K$ who are below the average KKM. For this reason both the class teacher and subject teachers provide remedial or assignments as an improvement in the value of the $A B K$ students.
\end{abstract}

Keywords: Inclusion learning model, Students with Disabilities, IPS 


\section{PENDAHULUAN}

Pendidikan yang diberikan harus sesuai dengan kebutuhan perkembangan anak. Anak difabel merupakan individu yang utuh dan unik. Mereka seperti anak-anak pada umumnya, memiliki hak untuk mendapatkan layanan pendidikan sesuai dengan kebutuhan mereka. Mereka memiliki hambatan intelektual tapi mereka juga masih memiliki potensi yang dapat dikembangkan sesuai dengan kapasitas yang dimiliki oleh mereka dan sesuai dengan kebutuhannya. Oleh karena itu maka layanan pendidikan yang diberikan kepada mereka diupayakan dapat mengembangkan potensi secara optimal sesuai dengan kebutuhan. Pemahaman baik secara teori maupun praktis sangat diperlukan supaya para professional dapat memberikan layanan pendidikan yang dapat memenuhi kebutuhan mereka (Nunung Apriyanto, 2012:11). Saat ini, pendidikan disekolah dapat ditempuh oleh siapapun dari berbagai kalangan dan golongan. Berbagai sekolah didirikan untuk menjadi tempat atau sarana pendidikan bagi anak, tanpa terkecuali anak-anak berkebutuhan khusus. Berbagai kurikulum juga dikembangkan untuk sekolah agar dapat membantu anak dalam proses pembelajaran yang baik dan bermutu (Rindi Lelly, 2014:1). Anak yang terlahir normal dengan mudah bisa mendapatkan pendidikan dimanapun yang diinginkannya. Tapi bagaimana dengan anak-anak yang terlahir dengan tidak normal, atau dengan kata lain mempunyai kebutuhan khusus, yang sering disebut dengan ABK (Anak Berkebutuhan Khusus). Pendidikan untuk ABK juga terdapat dalam UU Pendidikan Nasional No. 20 Tahun 2003 pasal 32 ayat 1, yaitu "pendidikan khusus merupakan pendidikan bagi peserta didik yang memiliki tingkat kesulitan dalam proses pembelajaranp karena kelainan fisik, emosional, mental, sosial, dan/atau memiliki potensi kecerdasan dan bakat istimewa". Berdasarkan UU tersebut, ABK juga berhak mendapatkan pendidikanpo, yang disebut dengan pendidikan khusus. Salah satu pendidikan khusus untuk ABK adalah sekolah luar biasa (SLB). Sekolah ini memiliki peranan dalam mengembangkan sistem pendidikan bagi ABK dalam ranah kognitif, afektif, dan psikomotorik. Namun, seringkali ABK yang bersekolah di SLB seolah didiskriminasikan dalam hal mendapatkan pendidikan dibanding sekolah normal. Dan juga lokasi SLB yang lebih banyak berada di ibukota Kabupaten kadang tidak bisa dijangkau oleh orang tua $A B K$ yang kadang berada di kecamatan desa yang jauh dari ibukota Kabupaten. Sedangkan sekolah umum yang dekat dengan tempat tinggal mereka belum memiliki sarana dan prasarana untuk menerima ABK. 
(Roza Susanti, 2012:88) Sejalan dengan perkembangan dan riset yang dilakukan oleh beberapa ahli, muncullah sistem pendidikan inklusi bagi anak berkebutuhan khusus. Akhirnya, istilah ini pun popular dalam dunia pendidikan di Indonesia. Khususnya pendidikan luar biasa (PLB). Model yang diberikan sekolah inklusi ini menekankan pada keterpaduan penuh, menghilangkan keterbatasan dengan menggunakan prinsip education for all.

Pendidikan khusus yang dimaksud dalam UU No 20 Tahun 2003 tersebut diatas menjelaskan bahwa pendidikan khusus diselenggarakan secara inklusi atau pada satuan pendidikan khusus. Oleh karena itu, pendidikan inklusi ini menjadi salah satu program Direktorat Pendidikan Luar Biasa mulai tahun 2001. Terlebih dengan dikeluarkannya Surat Edaran dari Direktorat Pendidikan Luar Biasa yang menginstruksikan kepada semua kabupaten/kota untuk mengembangkan sekolah inklusi di SD, SMP, SMA, SMK masing-masing satu sekolah (Ahmad Wasita, 2012:77-78).

$$
\text { Selanjutnya }
$$

Kementrian

Pendidikan Nasional (Kemendiknas) sebagai institusi yang bertanggung jawab meregulasi pendidikan mengeluarkan kebijakan melalui Peraturan Mentri Pendidikan Nasional (Permendiknas) No 70 Tahun 2009 tentang pendidikan inklusi sebagai solusi atas terjadinya diskriminasi bagi peserta didik yang berkebutuhan khusus agar mampu mengenyam pendidikan yang layak.

Di Indonesia, pendidikan khusus dilaksanakan melalui dua jalur, yaitu pada satuan pendidikan akademis (sekolah luar biasa) dan pada sekolah reguler (program pendidikan inklusi). Pemerintah melalui PP.No.19 tahun 2005 tentang Standar Nasional Pendidikan, pasal 41(1) telah mendorong terwujudnya sistem pendidikan inklusi dengan menyatakan bahwa setiap satuan pendidikan yang melaksanakan pendidikan inklusi harus memiliki tenaga kependidikan yang mempunyai kompetensi menyelenggarakan pembelajaran bagi peserta didik dengan kebutuhan khusus. Sesuai dengan turunnya Surat Keputusan WaliKota Payakumbuh Nomor: 800/035/SEKRE/2015 tahun 2015, Dipimpin langsung Kepala Sekolah Luar Biasa (SLB) Negeri Centre Payakumbuh Dewi Marza, S.Pd, SMP Negeri 4 Payakumbuh ditetapkan sebagai salah satu sekolah yang dapat melaksanakan pendidikan sekolah inklusi, dan dengan terlaksananya sekolah inklusi tersebut yang hampir berjalan kurang lebih 19 tahun, SMP Negeri 4 Payakumbuh sudah berbagai jenis dan macam-macam kemampuan belajar siswa. Subagio $(1999 ; 76)$ menyatakan didalam implementasi pelayanan dan proses 
pembelajaran $A B K$ di sekolah inklusi (termasuk SMP inklusi) terdapat beberapa bentuk kegagalan siswa $\mathrm{ABK}$ yang belajar di SMP regular inklusi, seperti halnya siswa tunanetra, mereka sering memperlihatkan motivasi belajar yang rendah, perilaku sering membolos bahkan sampai drop-out karena perasaan-perasaan rendah diri sulit bergaul dan berkomunikasi dengan teman-teman sebayanya yang normal. Meiyeni, N. (2000;119) mengutaran pada hasil penelitiannya bahwa masalahmasalah yang dihadapi siswa-siswa ABK mengikuti pembelajaran disekolah pada umumnya, sulit mendapatkan pelayanan pembelajaran yang bermutu oleh guru yang bermutu, bergaul, dan bekerja sama dengan teman sebayanya, kesulitan mencapai tugas-tugas perkembangannya yang seusianya memerlukan perbaikan layanan pendidikan, perhatian, komitmen, tindakan nyata serta dukungan penuh dari semua kalangan. Dengan demikian, sekolah penyelenggara pendidikan inklusif harus memiliki kemauan, kemampuan, dan kesiapan dalam merespon perbedaan atau keberagaman serta memahami keberadaan masingmasing siswanya salah satunya kompetensi seorang guru. Sunardi (2009) mengemukakan lebih jauh berkenaan dengan kondisi guru yakni “a.) keberadaan guru khusus masih dinilai belum sensitive dan proaktif terhadap permasalahan yang dihadapi ABK. b.) belum didukung dengan kejelasan aturan tentang peran, tugas, fungsi, dan tanggung jawab masing-masing guru. c.) Pelaksanaan tugas belum disertai dengan diskusi rutin yang tekait dengan penanganan masalah belajar siswa ABK. d.) hubungan guru kelas dengan guru pembimbing khusus (GPK) belum sinergis sehingga terkesan melayani siswa $\mathrm{ABK}$ belum kolaboratif". Terkait dengan kondisi diatas, dalam Permendiknas No 41 Tahun 2007, Standar Pendidikan Nasional tentang Standar Proses didalamnya mencakup perencanaan proses pembelajaran, maka guru sebelum melaksanakan proses pembelajaran harus dimulai dengan menyusun rencana pembelajaran yakni silabus, RPP, dan PPI. Perencanaan pembelajaran merupakan keseluruhan dari proses analisis kebutuhan dan tujuan belajar serta pengembangan sistem penyampaiannya untuk memenuhi kebutuhan dan mencapai tujuan belajar, termasuk di dalamnya pengembangan paket pembelajaran, kegiatan pembelajaran, uji coba dan revisi paket pembelajaran, dan terakhir kegiatan mengevaluasi program dan hasil belajar. Disinilah kompetensi dari menyusun perencanaan pembelajaran bagi seorang guru sangat diperlukan dalam keberhasilan proses pembelajaran yang akan dilaksanakan. SMP Negeri 4 Payakumbuh mengakui bahwa setiap 
individu memiliki keunikan sendiri, sehingga ia mempunyai kemampuan untuk berkembang menjadi dirinya sendiri dan menggapai prestasinya sendiri. SMP Negeri 4 Payakumbuh melaksanakan pembelajaran yang berbeda dengan sekolah reguler lainnya, karena menampung dan menerima peserta didik $A B K$ dengan persyaratan membawa hasil test psikologi serta surat rekomendasi dari sekolah sebelumnya. Dalam penanganan peserta didik ABK sekolah melakukan berbagai inovasi agar peserta didik ABK dapat mengikuti proses pembelajaran dengan baik. Hal itu juga dilakukan untuk memberikan penyadaran terhadap masyarakat bahwa peserta didik $A B K$ juga dapat bersekolah di sekolah umum bukan hanya di sekolah khusus seperti Sekolah Luar Biasa (SLB). SMP Negeri 4 Payakumbuh juga memberikan fasilitas dan guru pendamping bagi peserta didik $A B K$ untuk memudahkan mereka dalam proses pembelajaran di kelas.

Guru adalah orang yang bertanggung jawab terhadap pelaksanaan pendidikan dengan sasaran siswa, sedangkan menurut Sahertian (Maryono, 2011: 90), jabatan guru secara hakiki adalah panggilan untuk melayani anak yang diserah-tanggungjawabkan kepada mereka. Guru merupakan salah satu tokoh penting dalam praktek inklusi di sekolah, karena guru berinteraksi secara langsung dengan para siswa, baik siswa yang berkebutuhan khusus, maupun siswa non berkebutuhan khusus. Seorang guru diharapkan dapat memberikan kehidupan kelas agar menjadi lebih hangat dan pada waktu yang bersamaan dapat memberikan pemahaman kepada murid yang lain untuk dapat saling berinteraksi. Praktek inklusi merupakan tantangan baru bagi pengelola sekolah. Taylor dan Ringlaben (2012) menyatakan bahwa dengan adanya pendidikan inklusi menyebabkan tantangan baru pada guru, yaitu dalam hal melakukan perubahan yang signifikan terhadap program pendidikan dan mempersiapkan guru-guru untuk menghadapi semua kebutuhan siswa baik siswa berkebutuhan khusus maupun non berkebutuhan khusus.

Taylor dan Ringlaben juga menjelaskan mengenai pentingnya sikap guru terhadap inklusi, yaitu guru dengan sikap yang lebih positif terhadap inklusi akan lebih mampu untuk mengatur instruksi dan kurikulum yang digunakan untuk siswa bekebutuhan khusus, serta guru dengan sikap yang lebih positif ini dapat memiliki pendekatan yang lebih positif untuk inklusi. (Syafrida Elisa, Aryani Tri Wrastari, 2013:53). Proses pembelajaran inklusi merupakan suatu pembelajaran yang terjadi dimana terdapat anak berkebutuhan khusus belajar bersama-sama dengan anak lainnya yang normal dalam satu sekolah 
reguler. Dalam proses belajar mengajar di kelas inklusi masing-masing guru memiliki cara dan pola pikir yang tersendiri dalam membuat rencana pembelajaran, namun pada dasarnya guru tersebut sepakat bahwa perencanaan pembelajaran perlu disesuaikan dengan karakteristik peserta didik dikelas mereka. Guru Mata Pelajaran IPS Terpadu disekolah ini berjumlah 7 orang dengan 2 orang lakilaki dan 5 orang perempuan. Untuk guru yang berumur dibawah 45 tahun lebih aktif dalam menciptakan suasana belajar mengajar dikelas dengan berbagai model pembelajaran, sehingga siswa-siswi tersebut lebih aktif dalam proses belajar mengajar.

Sedangkan sebagian guru yang berumur 45 keatas memiliki banyak kendala yang dialami seperti kurangnya inisiatif dalam menciptakan suasana belajar mengajar dikelas, dan juga faktor usia yang menunjukkan guru tersebut memiliki suatu penyakit sehingga sulituntuk berperan aktif dalam suatu proses belajar mengajar, hanya saja guru tersebut lebih fokus dalam hal ceramah dan pemberian tugas, sehingga peserta didik merasa jenuh dan bosan dalam belajar, khususnya ABK.

Permasalahan yang dihadapi guru didalam kelas inklusi diantaranya: GPK tidak memadai dengan jumlah anak yang terdapat disekolah, kurangnya pemahaman guru terhadap kebutuhan \& karakter $A B K$, masih ada beberapa guru yang belum paham dengan adanya pendidikan inklusi karena merupakan guru baru, sehingga dalam pembelajaran dikelas belum menggunakan model/metode pembelajaran yang dapat membantu proses belajar mengajar pada kelas inklusi. Guru cenderung memikirkan strategi dalam mengajar, metode yang di gunakan masih menggunakan metode ceramah, dan kurang memperhatikan keterlibatan siswa dalam kegiatan pembelajaran.

Padahal sekolah SMP Negeri 4 Payakumbuh ini memakai kurikulum reguler (K13), namun masih terdapat guru yang mengajar lebih aktif daripada siswa. Hasil belajar yangdicapai ABK ini dari tahun ke tahun cukup bagus, ada yang diatas rata-rata KKM sekolah, \& ada yang dibawah rata-rata KKM sekolah. Untuk nilai yang dibawah ratarata KKM sekolah biasanya guru mata pelajaran melakukan remedial terhadap siswa tersebut. Jadi diketahui bahwa dari KKM 75 yang ditargetkan sekolah. Guru bidang studi mengandalkan GPK selalu mendampinginya, padahal jumlah GPK yang ada disekolah tersebut terbatas. Selanjutnya, minimnya sarana penunjang sistem pendidikan inklusi, terbatasnya pengetahuan dan keterampilan yang dimiliki oleh para guru sekolah inklusi menunjukkan bahwa 
sistem pendidikan inklusi belum dipersiapkan dengan baik. Apalagi kurikulum pendidikan umum yang ada sekarang belum mengakomodasi keberasaan anak berkebutuhan khusus. Sehingga nampaknya program penyelenggaraan pendidikan inklusi hanya terkesan program eksperimental. Kondisi ini jelas menambah beban tugas yang harus diemban para guru yang berhadapan langsung dengan persoalan teknis disekolah. Disatu sisi para guru harus berjuang keras memenuhi tuntutan hati nurani untuk membekali pengetahuan seluruh siswanya, sementara di sisi lain para guru tidak memiliki keterampilan yang cukup untuk menyampaikan materi pembelajaran kepada siswa berkebutuhan khusus.

Kondisi kelas yang seperti ini bukannya menciptakan kondisi eksklusifisme bagi siswa berkebutuhan khusus dalam lingkungan kelas reguler. Jelas ini menjadi fenomena tersendiri bagi para guru yang di dalam kelasnya terdapat anak berkebutuhan khusus. ( $N$. Praptiningrum, 2010:35) Menjadi sekolah inklusi seperti di SMP Negeri 4 Payakumbuh memang tidak mudah. Setidaknya sekolah harus memperbaiki diri dengan inovasi-inovasi agar siswa difabel dapat mengikuti proses pembelajaran dengan baik. Disamping itu, sekolah juga harus bisa memberikan penyadaran kepada semua akademik bahwa siswa-siswi difabel juga bisa mengikuti pendidikan di sekolah umum. Penyusunan kurikulum, metode mengajar, media pembelajaran, kompetensi guru, evaluasi, dan layanan akademik maupun nonakademik harus disusun sedemikian rupa yang tentunya memerlukan waktu dan biaya yang tidak sedikit.

\section{Model Pembelajaran}

Menurut Joyce dan Weil (2000:13) mengemukakan maksud dari model pembelajaran adalah suatu perencanaan atau suatu pola yang digunakan sebagai pedoman dalam merencanakan pembelajaran di kelas atau pembelajaran dalam tutorial dan untuk menentukan perangkat pembelajaran. Selanjutnya, Joyce menyatakan bahwa model pembelajaran mengarahkan kita ke dalam perancangan pembelajaran untuk membantu peserta didik sedemikian rupa sehingga tujuan pembelajaran itu tercapai (Hernani, dkk:5). T. Raka Joni (1980) membahas model-model pembelajaran dalam konteks pembahasan strategi pembelajaran. Dalam pembahasannya tersebut ada kesan bahwa model-model pembelajaran dipandang setara kedudukannya dengan strategi pembelajaran. Dipihak lain Wina Sanjaya (2005) berpendapat bahwa model pembelajaran berkedudukan lebih tinggi (lebih umum) dari pada strategi pembelajaran. (Toto Ruhimat, 
dkk, 2011:198-199) Model pembelajaran mempunyai empat ciri khusus yang tidak dimiliki oleh strategi, metode, atau prosedur.

Ciri-ciri tersebut ialah: (1) rasional teoritis logis yang disusun oleh para pencipta atau pengembangnya; landasan pemikiran tentang apa dan bagaimana siswa belajar (tujuan pembelajaran yang akan dicapai); (3) tingkah laku mengajar yang diperlukan agar model tersebut dapat dilaksanakan dengan berhasil; (4) lingkungan belajar yang diperlukan agar tujuan pembelajaran itu dapat tercapai (Kardi dan Nur, 2009).Menurut Johnson (dalam Samani, 2000), untuk mengetahui kualitasmodel pembelajaran harus dilihat dari dua aspek, yaitu proses dan produk. Aspek Proses mengacu apakah pembelajaran mampu menciptakan situasi belajar yang menyenangkan (joyful learning) serta mendorong siswa siswa untuk aktif belajar dan berpikir kreatif.

Proses mengandung makna tuntutan peristiwa atau kegiatan, sedangkan pembelajaran adalah suatu kombinasi yang tersusun meliputiunsurunsur manusiawi, material, fasilitas, perlengkapan dan prosedur yangsaling mempegaruhi untuk mencapai tujuan pembelajaran (Dr. OemarHamalik, 2005: 57). Dalam sistem pembelajaran terdapat tiga ciri khasyang terkandung di dalamnya, yaitu, rencana, saling ketergantungan, dan tujuan. Proses pembelajaran, pada hakekatnya, adalah untuk mendewasakan siswa melalui upaya untuk membekali siswa dengan pengetahuan, sikap, dan keterampilan yang dapat menjadi bekal bagi kehidupannya. Bekal yang dimiliki siswa itu sangat penting sebagai sumber daya manusia yang dibutuhkan dalam kehidupan, baik untuk diri sendiri, masyarakat, bangsa maupun negara (Nahdatul Azmi, 2006:1).

Proses pembelajaran adalah berjalannya suatu pembelajaran dalam suatu kelas. Peneliti melakukan analisis pada proses pembelajaran yang meliputi aspek kegiatan awal pembelajaran, kegiatan inti pembelajaran, dan kegiatan akhir pembelajaran. Proses pembelajaran bertujuan agar siswa mampu mengembangkan kemampuan fisik maupun psikis ke dalam tiga ranah. Sehingga pembelajaran yang berlangsung akan lebih bermakna. Tidak hanya sebatas pengetahuan saja, namun lebih pada pengalaman ilmu dan ketrampilan menciptakan sesuatu sebagai hasil pemahaman ilmu tertentu. Proses pembelajaran dikatakan berhasil secara optimal jika sebagian besar (84\% s.d. 94\%) bahan pengajaran yang diajarkan dapat dikuasai siswa. Secara tidak langsung proses pembelajaran dipengaruhi oleh perencanaan yang baik yang dapat kita lihat dari rencana pelaksanaan pembelajaran. Untuk 
mengetahui optimalnya metode pembelajaran inquiri dapat dilihat pada hasil belajar. Jadi, secara umum dapat disimpulkan bahwa optimalnya proses pembelajaran dipengaruhi oleh rencana pelaksanaan pembelajaran dan optimal atau belum metode inquiri dapat dilihat melalui hasil pembelajaran yang telah dilaksanakan. (Rindy Lelly,2014:10-11)

Pendidikan inklusi adalah sebuah sistem pendidikan yang memungkinkan setiap anak penuh berpartisipasi dalam kegiatan kelas reguler tanpa mempertimbangkan kecacatan atau karakteristik lainnya. Disamping itu pendidikan inklusi juga melibatkan orangtua dalam cara yang berarti dalam berbagai kegiatan pendidikan, terutama dalam proses perencanaan, sedang dalam belajar- mengajar, pendekatan guru berpusat pada anak (Meita Shanty,2012:64-65). Pendidikan inklusi oleh Sapon-Sevin (O’Neil, 1994/1995) didefinisikan sebagai system layanan PLB yang mempersyaratkan agar semua anak luar biasa dilayani di sekolahsekolah terdekat di kelas biasa bersama teman-teman seusianya. Oleh karena itu, beliau menekankan adanya restrukturisasi di sekolah sehingga menjadi komunitas yang mendukung pemenuhan kebutuhan khusus setiap anak, artinya kaya dalam sumber dan dukungan dari semua guru dan siswa.

Ahli yang lain, Stainback dan Stainback (1990) dalam Sunardi (2009) mengatakan bahwa sekolah yang inklusi adalah sekolah yang menampung semua murid di kelas yang sama. Sekolah ini menyediakan program pendidikan yang layak, menantang, tetapi sesuai dengan kemampuan dan kebutuhan setiap murid maupun bantuan dan dukungan yang dapat diberikan oleh para guru agar anak-anak berhasil. Lebih dari itu, sekolah inklusi juga merupakan tempat bagi setiap anak dapat diterima, menjadi bagian dari kelas tersebut, dan saling membantu, baik dengan guru dan teman sebayanya maupun anggota masyarakat lain agar kebutuhan individunya terpenuhi. (Emirfan TM, 2012:30-31)

Direktorat PBLS dalam Depdiknas (2007) menjelaskan pendidikan inklusi merupakan sistem layanan pendidikan yang mengikut sertakan anak berkebutuhan khusus belajar bersama dengan anak sebayanya di sekolah reguler yang terdekat dengan tempat tinggalnya. Penyelenggaraan pendidikan inklusi menuntut pihak sekolah melakukan penyesuaian baik dari segi kurikulum, sarana dan prasarana pendidikan, maupun system pembelajaran yang disesuaikan dengan kebutuhan individu peserta didik. (Roza Susanti,2012: 94) Perkembangan pendidikan inklusi tersebut dilakukan dengan menggunakan pendekatanpendekatan (Depdiknas (2007, 5), sebagai berikut: 


\section{Pendekatan segregasi}

Pendekatan segregasi adalah metode pendidikan yang memisahkan anak kebutuhan khusus dari sistem persekolahan reguler.Di Indonesia bentuk sekolah segregasi ini berupa satuan pendidikan khusus atau Sekolah luar biasa sesuai dengan jenis kelainan peserta didik. Sebagai satuan pendidikan khusus, makasistem pendidikan yang digunakan terpisah sama sekali dari sistempendidikan di sekolah reguler, baik kurikulum, tenaga pendidik, dan kependidikan, sarana prasarana, sampai pada sistem pembelajaran dan evaluasinya. Kelemahan dari sekolah segregasi ini antara lain aspek perkembangan emosi dan sosial anak kurang luas karena lingkungan pergaulan yang terbatas.

2. Pendekatan terpadu (integrated)

Pendekatan terpadu adalah pendekatan yang memberikan kesempatan kepada peserta didik berkebutuhan khusus untuk mengikuti pendidikan di sekolah reguler tanpa adanya perlakuan khusus yang disesuaikan dengan kebutuhan individu anak. Sekolah tetap menggunakan kurikulum, sarana prasarana, tenaga pendidik dan kependidikan, serta sistem pembelajaran reguler untuk semua peserta didik. Jika ada peserta didik tertentu mengalami kesulitan dalam mengikuti pendidikan, maka konsekuensinya peserta didik itu sendiri yang harus menyesuaikan dengan sistem yang dituntut di sekolah reguler. Dengan kata lain pendidikan terpadu menuntut anak yang harus menyesuaikan dengan sistem yang dipersyaratkan sekolah reguler.

3. Sekolah inklusi

Pendekatan inklusi merupakan perkembangan baru dari pendidikan terpadu. Pada sekolah inklusi setiap anak sesuai dengan kebutuhan khususnya, semua diusahakan dapat dilayani secara optimal dengan melakukan berbagai modifikasi dan/atau penyesuaian, mulai dari kurikulum, sarana prasarana, tenaga pendidik dan kependidikan, sistem pembelajaran sampai pada sistem penilaiannya. Dengan kata lain pendidikan inklusi mensyaratkan pihak sekolah yang harus menyesuaikan dengan tuntutan kebutuhan individu peserta didik, bukan peserta didik yang menyesuaikan dengan sistem persekolahan.

Keuntungan dari pendidikan inklusi anak berkebutuhan khusus maupun anak biasa dapat berinteraksi secara wajar sesuai dengan tuntutan kehidupan sehari-hari di masyarakat, dan kebutuhan pendidikannya dapat terpenuhi sesuai potensinya masingmasing. Konsekuensi penyelenggaraan pendidikan inklusi adalah pihak sekolah dituntut melakukan berbagai perubahan, mulai cara pandang, sikap, sampai pada proses pendidikan yang 
berorientasi pada kebutuhan individu tanpa diskriminasi. (Roza Susanti, 2012:92-94)

\section{Model Pendidikan Inklusi Indonesia}

Pendidikan anak berkebutuhan khusus di sekolah inklusi dapat dilakukan dengan berbagai model sebagai berikut (Ashman, 1994 dalam Emawati, 2008):

1. Kelas Reguler (Inklusi Penuh) Anak berkebutuhan khusus belajar bersama anak non berkebutuhan khusus sepanjang hari di kelas reguler dengan menggunakan kurikulum yang sama.

2. Kelas Reguler dengan Cluster Anak berkebutuhan khusus belajar bersama anak non berkebutuhan khusus di kelas reguler dalam kelompok khusus.

3. Kelas Reguler dengan Pull Out Anak berkebutuhan khusus belajar bersama anak non berkebutuhan khusus di kelas reguler namun dalam waktuwaktu tertentu ditarik dari kelas reguler ke ruang lain untuk belajar dengan guru pembimbing khusus.

4. Kelas Reguler dengan Cluster dan Pull Out Anak berkebutuhan khusus belajar bersama anak non berkebutuhan khusus di kelas reguler dalam kelompok khusus, dan dalam waktu-waktu tertentu ditarik dari kelas reguler ke ruang lain untuk belajar dengan guru pembimbing khusus.

5. Kelas Khusus dengan Berbagai Pengintegrasian Anak berkebutuhan khusus belajar di dalam kelas khusus pada sekolah reguler, namun dalam bidangbidang tertentu dapat belajar bersama anak non berkebutuhan khusus di kelas reguler.

6. Kelas Khusus Penuh Anak berkebutuhan khusus belajar di dalam kelas khusus pada sekolah reguler. (Syafrida Elisa, Aryani Tri Wrastari, 2013:3)

\section{METODE PENELITIAN}

Penelitian ini menggunakan pendekatan kualitatif dengan menggunakan beberapa langkah observasi, wawancara mendalam dan angket yang diberikan kepada siswa dan guru. Kenudian data tersebut di analisis sehingga ditemukan temuan-temuan sebagai hasil penelitian.

\section{PEMBAHASAN}

Untuk RPP dan Silabus tidak ada dilakukannya pemodifikasian bagi anak berkebutuhan khusus (ABK). Untuk itu, baik siswa $A B K$ maupun siswa normal lainnya menggunakan RPP dan Silabus yang sama, hanya saja nanti dalam pelaksanaannya yang berbeda, dimana untuk anak berkebutuhan khusus 
diperlakukan secara khusus sesuai dengan kebutuhannya. Selain itu,

siswa $A B K$ didampingi oleh guru pendamping khusus pada saat mereka (ABK) sulit untuk memahami \& menerima pelajaran dari guru atau pada saat guru kelas maupun guru mata pelajaran tidak mampu menangani atau tidak mengerti apa kebutuhan siswa ABK tersebut. Kurikulum yang dipakai siswa ABK juga kurikulum sekolah yaitu (K13), dimana kurikulum ini menuntut siswa yang lebih aktif dan guru hanya sebagai fasilitator saja. Untuk itu sulit bagi mereka (ABK) bisa menyamaratakan kemampuan mereka (ABK) dengan siswa normal lainnya. Akibatnya sebagian siswa ABK tidak mampu untuk mencapi nilai hasil belajar mereka mencapai KKM.

Dalam proses pembelajaran berlangsung, setiap guru kelas maupun guru mata pelajaran menggunakan strategi dan metode pembelajaran menggunakan strategi dan metode pembelajaran yang berbeda-beda sesuai dengan kemampuan belajar siswa. Sebagian siswa berkebutuhan khusus mampu memahami dan menerima materi pembelajaran yang diberikan oleh guru, namun masih terdapat juga siswa berkebutuhan khusus yang tidak paham sama sekali dengan cara guru mengajar didalam kelas. Interaksi siswa ABK dengan siswa normal cukup baik, walaupun sewaktu-waktu siswa normal sering mencemooh siswa $A B K$ "bercanda", namun setelah itu siswa normal ini meminta maaf kepada siswa ABK. Lebih menariknya lagi siswa normal banyak belajar mengenai keterbatasan tertentu dan saling mengembangkan keterampilan sosial dengan siswa $A B K$, dan saling berbagi cerita satu sama lain. Model inklusi yang dgunakan pada saat proses pembelajaran ialah bentuk kelas reguler (inklusi penuh) dan kelas reguler dengan pull out. Diantara kedua model tersebut sebenarnya sama-sama efektif, namun lebih efektif lagi jika siswa berkebutuhan khusus yang memiliki kelainan berat belajar dikelas inklusi, karena jika di kelas reguler suasana kelas sangat ribut ditambah lagi dengan siswa lainnya yang hoby mengganggu teman sebayanya. Maka dari itu agar lebih mudah bagi siswa ABK ini menerima materi yang diberikan guru kelas maupun guru mata pelajaran, lebih baik di kelas inklusi agar guru pendamping khusus mudah memberikan materi kepada siswa ABK ini.

Untuk anak Tunarungu, biasanya guru kelas maupun guru mata pelajaran sangat sulit untuk menghadapi siswanya, dikarenakan sangat sulit bagi mereka untuk bisa memahami materi yang telah disampaikan oleh guru, itu dikarenakan mereka tidak didukung oleh alat bantu dengar. Untuk itu sangat sulit bagi guru dalam memberi materi \& sangat sulit bagi siswa dalam menerima materi yang 
diberikan oleh guru. Maka dari itu, guru kelas maupun guru mata pelajaran meminta guru pendamping khusus membantu siswa $A B K$ untuk memahami materi yang diberikan guru. Untuk anak Tunagrahita, biasanya sebagian guru kelas maupun guru mata pelajaran menyerahkan sepenuhnya kemauan anak tersebut, karena sebagian anak tersebut lebih sibuk akan dirinya sendiri. Pada saat terjadi proses pembelajaran dikelas, biasanya anak ini keluar masuk sesuka hatinya saja, apalagi jika anak tersebut tidak menyukai guru maupun pelajarannya.

Untuk anak Lamban Belajar, biasanya guru kelas mapun guru mata pelajaran sering bertanya \& mendampingi anak ini, karena anak ini membutuhkan pendekatan individual secara khusus. Pada saat proses pembelajaran terjadi didalam kelas, guru kelas maupun guru mata pelajaran selalu berada disampingnya, mencoba untuk mengulangi materi kepada anak tersebut. Tetapi jika anak tersebut tidak mampu mengerti juga, maka guru kelas menyerahkannya kepada guru pendamping khusus, dan GPK tersebut yang membantu mengulangi materi berulang kali kepada anak tersebut sampai anak tersebut mampu mengerti \& paham.

Dan untuk anak Tunadaksa, guru kelas maupun guru mata pelajaran tidak ada masalah. Hanya saja bermasalah pada teman sebaya maupun teman sebangkunya saja, karena biasanya anak Tunadaksa ini sering bermain \& bercanda tawa pada teman sebangkunya. Untuk itu biasanya guru memisahkan mereka dengan jarak yang berjauhan.

Bagi anak berkebutuhan khusus tidak dibenarkan untuk bersikap kasar ataupun memaharinya, karena akan mengakibatkan pola pikir dan mental anak drop. Untuk itu, bagi guru kelas maupun guru mata pelajaran lebih memperhatikan kebutuhan siswa ABK tersebut. Untuk nilai hasil belajar siswa berkebutuhan khusus bisa dikatakan sudah baik, walaupun sebagian anak berkebutuhan khusus masih terdapat nilainya dibawah KKM. Pihak sekolah membenarkan bagi para guru untuk memberikan nilai standar KKM bagi siswa $A B K$, karena untuk siswa $A B K$ nilai mereka harus mencapai KKM, walaupun mereka tidak mengikuti ujian nasional (UN), tetapi mereka akan mendapatkan selembaran ijazah/STTB (Surat Tanda Tamat Belajar) untuk digunakan dengan semestinya.

Dengan demikian, penulis mendapatkan suatu gambaran bahwasanya nilai hasil belajar siswa ABK yang tidak mencapai KKM, disebabkan karena sikap mereka yang sangat kurang, kurang efektifnya proses pembelajaran didalam kelas, kurang aktifnya guru menggunakan model atau 
media yang membuat siswa ABK maupun normal lainnya merasa paham \& tidak membosankan, guru umum kurang memahami kebutuhan siswa ABK dalam proses pembelajaran. Untuk itu, seharusnya sebelum melakukan proses pembelajaran dalam suatu kelas, guru seharusnya terlebih dahulu membuat perencanaan pembelajaran, sehingga dengan adanya perencanaan yang matang dan siap, maka tujuan yang ingin kita capai akan memuaskan. Selain itu, guru harus mampu menciptakan iklim belajar yang kondusif sehingga anak-anak merasa nyaman belajar disekolah/dikelas, memberikan program pengajaran remedi, reptisi, pengayaan, dan tugas bagi peserta didik yang membutuhkan. Dan yang paling penting guru kelas/guru mata pelajaran selalu berkoordinasi dengan guru pendamping khusus demi perkembangan siswa ABK. Bahwasanya pendidikan inklusi di SMP N 4 Payakumbuh ini sudah baik, hanya saja dalam pelaksanaanya masih kurang. Sebagai contoh, guru umum masih banyak yang belum memahami kebutuhan anak $A B K$ tersebut sehingga mengakibatkan anak $A B K$ ini tidak aktif maupun tidak berkembang bakat yang dimilikinya. Siswa berkebutuhan khusus ini memerlukan bimbingan serta perlakuan khusus dari orang tersekat seperti guru, orang tua, maupun teman sebayanya. Namun dibalik itu semua ada kelebihan dari pendidikan inklusi ini ialah tidak adanya perbedaan diantara anak normal dengan anak yang memiliki berkebutuhan khusus dalam pendidikan, karena semua orang memiliki hak yang sama dalam belajar, serta dapat bersosialisasi dengan luas sehingga mampu menyesuaikan diri dengan lingkungan secara optimal dengan berbagai keragaman yang berbeda-beda. Dan untuk kekurangannya ialah tidak berkembangnya bakat siswa $A B K$ di sekolah inklusi karena sebagian dari mereka merasa tidak percaya diri akan kemampuan yeng mereka miliki serta kurangnya dukungan para orang tua akan kemampuan anaknya, sehingga para orang tua tidak memperhatian kemampuan yang dimiliki putra putrinya sendiri.

Selain itu juga terdapat kebiajakan sekolah diantaranya: Sekalipun sudah didukung dengan visi yang cukup jelas, menerima semua jenis anak cacat, sebagian sudah memiliki guru khusus, mempunyai catatan hambatan belajar pada masing-masing $\mathrm{ABK}$, dan kebebasan guru kelas dan guru khusus untuk mengimplementasikan pembelajaran yang lebih kreatif dan inovatif, namun cenderung belum didukung dengan koordinasi dengan tenaga profesional, organisasi atau institusi terkait. Serta masih terdapat kebijakan yang kurang tepat, yaitu guru kelas tidak memiliki tangung jawab pada kemajuan belajar ABK, serta keharusan 
orang tua $\mathrm{ABK}$ dalam penyediaan guru khusus. Walaupun demikian, SMP N 4 Payakumbuh ini masih menerima atau membuka lapangan pendidikan bagi siswa berkebutuhan khusus, karena pihak sekolah mampu untuk mengembangkan prestasi siswa ABK baik di bidang akademik maupun di bidang skill mereka masing-masing, walaupun masih terdapat kekurangan atau kendala yang dihadapi para guru dan siswa tersebut.

\section{KESIMPULAN}

Penelitian ini menghasilkan beberapa kesumpula yakni:

1. Perencanaan pembelajaran di sekolah inklusi tidak jauh berbeda dengan sekolah reguler. Perencanaan pembelajaran di sekolah inklusi tidak dilakukannya pemodifikasian RPP maupun silabus, dimana RPP untuk anak $A B K$ dijadikan satu dengan RPP untuk peserta didik normal.

2. Kurikulum yang digunakan di SMPN $\quad 4 \quad$ Payakumbuh menggunakan kurikulum sekolah reguler (K-13), dimana siswa lebih aktif daripada guru, guru hanya saja sebagai fasilitator.

3. Pengajaran kepada siswa difabel dilakukan bersamaan dengan siswa normal dalam satu kelas dengan model inklusi penuh, dengan penambahan dan penyediaan guru pembimbing khusus (GPK) yang bertugas sebagai konsultan maupun fasilitator bagi guru mata pelajaran dan siswa difabel.

4. Siswa difabel dapat mengikuti pembelajaran disekolah dengan baik. Hal ini disamping sekolah mempunyai guru pembimbing khusus, juga adanya dukungan dari berbagai pihak yang mendukung terselenggaranya pendidikan inklusi. Hanya saja masih terdapat hambatanhambatan dalam pembelajaran inklusi seperti kurang memadainya GPK dengan jumlah siswa difabel, langkanya peralatan bagi siswa difabel, dan tumbuhnya paradigma masyarakat tentang pentingnya pendidikan berbasis inklusi.

5. Untuk menjadi GPK tidaklah mudah, karena dalam pendidikan inklusi ini selain guru bidang studi dan orang tua, GPK juga memiliki peranan yang sangat penting dalam pelaksanaannya pendidikan inklusi ini, karena GPK lah yang mampu memahami segala sesuatu yang dibutuhkan dan diinginkan oleh siswa $A B K$ tersebut. GPK harus memahami kendala atau setiap hambatan yang dimiliki siswa $A B K$, selain 
itu GPK juga harus bekerja sama dengan guru bidang studi serta orang tua dan GPK lainnya yang berada di luar sekolah untuk menambah wawasan yang luas.

\section{DAFTAR PUSTAKA}

Ahmad Wasita,2012, Seluk - Beluk Tunarungu \& Tunawicara Serta Strategi Pembelajarannya. Jogjakarta: Javalitera.

Ardhi, Wijaya, 2012,Memahami Anak Tuna Rungu. Yogyakarta: Familia.

Ardhi, Widjaya, 2012,Seluk - Beluk Tunanetra \& Strategi Pembelajarannya.Jogjakarta: Javalitera

Bilqis, 2012, Lebih Dekat Dengan Anak Tuna Daksa. Yogyakarta: Familia.

Dian, Nafi, 2012, Pantang Menyerah Mengasuh Asih Anak Berkebutuhan Khusus. Yogyakarta: Familia

.Emirfan TM, 2012Panduan Lengkap Orangtua \& Guru Untuk Anak Dengan Diskalkulia (Kesulitan Menghitung). Jogjakarta: Javalitera

Meita Shanty, 2012, Strategi Belajar Khusus Untuk Anak Berkebutuhan Khusus. Yogyakarta: Familia ..Misbach D, 2012,Seluk - Beluk Tunadaksa \& Strategi
Pembelajarannya. Jogjakarta: Javalitera.

Nahdatul, Hazmi. 2006. "Proses Pembelajaran Sejarah Yang Mencakup Pengembangan Aspek Afektif Siswa Dalam Memahami Fakta-Fakta Sejarah". (Tesis). Padang: Universitas Negeri Padang

Roza, Susanti. 2012. "Paradigma Pendidikan Inklusif”. (Edukasi Jurnal Vol.1No.2. Juli 2012). Payakumbuh: STKIP Abdi Pendidikan Payakumbuh.

Dwi Yanti, Fiona Putri. 2012. “Proses Pembelajaran Pada Sekolah Dasar Inklusi". (Edukasi Jurnal Ilmiah Pendidikan Khusus (EJUPEKhu:Pdf)Vol.1 No. 3. September 2012). (Pdf). Padang: Universitas Negeri Padang.

Gallan Berkah Mahesa, Dkk. 2013. "Perencanaan Pembelajaran Oleh Guru Di SMP Negeri 23 Padang Dalam Setting Inklusi". (Edukasi Jurnal Ilmiah Pendidikan Khusus (E-JUPEKhu:Pdf) Vol.2 No. 3. September 2013). (Pdf) Padang: FIP Universitas Negeri Padang.

Syafrida Elisa, Aryani Tri Wrastari. 2013. "Sikap Guru Terhadap PendidikanInklusi Di Tinjau Dari Faktor Pembentuk Sikap". (Jurnal PsikologiPerkembangan 
Jurnal HISTORIA Volume 6, Nomor 2, Tahun 2018, ISSN 2337-4713 (e-ISSN 2442-8728)

dan Pendidikan Vol.2 No.01.April 2013). (Pdf) Surabaya:Fakultas Psikologi Universitas Airlangga Surabaya.

N, Praptiningrum. 2010. “Fenomena Penyelenggaraan Pendidikan Inklusif BagiAnak Berkebutuhan
Khusus". (Jurnal Pendidikan Khusus Vol.7 No. 2.November 2010). (Pdf). Yogyakarta: FIP Universitas Negeri Yogyakarta.

Hernani, dkk. "Manajemen Pendidikan Anak Berkebutuhan Khusus (ABK)". Universitas FKIP Unilak 
Model Pembelajaran Inklusi pada Mata..., Syirwana Mayasari Hb \& Nahdatul Hazmi, 161-178 